\title{
Working and retiring in sunny Spain: Lifestyle migration further explored
}

\author{
JuAN PARREÑO-CASTELLANO and JosEFINA DOMÍNGUEZ-MUJICA ${ }^{1}$
}

\begin{abstract}
Spanish tourism destinations have received immigrant workers and retirees from Western and Northern Europe since the sixties. In this paper we focus on the specific group of the retirees who had worked previously in Spain with the objective to quantify them, to interpret the reasons why they migrated and have remained in the Spanish tourism areas, and to acknowledge the relationship between tourism and migration in this context. The empirical research is based on the combination of quantitative and qualitative information. In particular, we have used official statistical sources, semi-structured in-depth interviews and the micro-data from the National Immigrant Survey (ENI) and the Continuous Sample of Labour Life (MCVL). The method used is a mix of transversal and longitudinal analysis revealing that, despite the difficulties to quantity the studied group, labour motivations must be put into question and the role of tourism becomes the core of the explanation of the migration process.
\end{abstract}

Keywords: tourism labour market, retirees, Spanish tourism destinations, lifestyle

\section{Introduction}

Since the 1960s Spanish tourism destinations have been at the receiving end of two main international migration inflows from Northern and Western Europe: a group of immigrant workers of different occupational profiles that have arrived in different intensity over time; and an inflow of non-working immigrants that have also varied in intensity and profile. The latter has been traditionally broken down into alternatively described as retirement migration, lifestyle migration or residential migration.

This paper focuses on a type of migration from Northern and Western Europe that occupies an intermediate position between the two inflows above: retired Europeans who arrive to Spanish tourism destinations while they are still active. These migrants can be classified as belonging to either of the aforementioned groups given that they were workers in Spanish tourism areas but their migration process was motivated for reasons similar to those of non-working migrants. Migration did not entail a considerable improvement of the economic conditions of these migrants, who were rather looking for a change of direction in their lives, just like lifestyle migrants. Therefore, this migration process needs indeed to be examined within the context of lifestyle migrations, broadening the perspective of the complex and close relationships between production and consumption within the migration flows (Williams, A. and Hall, C.M. 2000).

Spain's coastal regions offered in past decades ideal conditions for these migrants to fulfil their projects. On the one hand, they personally experienced their dreamt life in a real environment; on the other hand, they benefited from the labour opportunities that the tourist business created. Following the idea of the methodological dualism analyzed

\footnotetext{
${ }^{1}$ Department of geography, University of Las Palmas de Gran Canaria. C/Perez de Toro 1. 35003 Las Palmas, Spain. E-mails: juan.parreno@ulpgc.es, josefina.dominguezmujica@ulpgc.es
} 
by BAKEWELL, O. in his reflections on structure and agency in migration theory (2010), this article reveals the bracket between the strategic conduct of individuals and the structuring order of the labor market in tourism destinations.

Our paper establishes the following two main hypotheses. First, that we are not dealing with a flow of migrant workers, but with lifestyle migrants sensu lato, who do not wish to wait until retirement to start a new life project focused on leisure and a better quality of life. In other words, this group of migrants of working age wish to settle in Spain's coastal areas and share the lifestyle of tourists and retirees alike. The second hypothesis is that the permanence of these people, who will later become retired migrants, can only be explained if we consider the tourism activity. This is a phenomenon related to the tourism destinations, and motivated by tourism activity and leisure. Subsequently to these hypotheses, we have established three objectives in our analysis: (i) to quantify the group object of this study; (ii) to interpret the reasons why they migrated and have remained in Spanish tourism regions; and (iii) to acknowledge the relationship between tourism and migration in this context.

The paper has been divided into five sections. In the first, we introduce some ideas that allow for a better contextualization of the study's aim and its underlying hypotheses. Secondly, we explain the sources and the methodology used in our research. Under the third and fourth heading, we describe the main characteristics of European workers and retirees in Spanish tourism destinations and the relationship between workers and retirees. In particular, we analyse the quantitative dimension of retirees after working in Spain, bio-demographic profiles, their linkages with tourism and their challenging identification as labour or retired migrants. We also explain the characteristics that make it possible to analyse their migration projects and the reasons why they have stayed in Spain after retirement. The article ends with some final suggestions for further discussion.

\section{Research framework: from retirement migration to retirement of labor migrants}

Tourism destinations have become places where a variety of processes of international human mobility coexists. Besides tourist flows, we can differentiate 'labour migration', 'entrepreneurial migration', 'return (labour) migration', 'consumption-led economically active migration' and 'retirement migration' (Williams, A. and Hall, C.M. 2002) that have given rise to the development of specific lines of research, particularly on international retirees' migration (BENSON, M and O'Reilly, K. 2009). In the case of Spain, this topic has been profoundly studied both in Spain itself and in the countries of origin of these immigrants, as well as by teams of researchers from both provenances.

From a quantitative point of view, studies of the international migration flow of retirees have been approached by means of a statistical analysis of the data on stock and flows of elderly foreigners residing at tourism destinations. Therefore, the figures of retirement migrations have been associated with permanent migrations, which normally imply home ownership and registration in the municipal census. However, under the relocation of retirees other non-registered flows should be included, given the wideranging nature of mobility processes, which can include second-home owners who stay for short periods of time, or the seasonal migrants who rent a property (KING, R. et al. 2000) and who tend not to register as residents in their host municipalities.

This has led researchers to establish different categories of retired migrants, differentiating between permanent and seasonal migrants, visitors and returnees (O'ReILly, K. 1995). International retirement migration in tourism destinations is consequently a mixture of sensu stricto migratory flows and residential tourism (O'Reilly, K. 2007; Huete, R. et al. 2008), because there is a lack of 'clear boundaries between international residential migration and either seasonal or circulatory migration or residential tourism' (BožIć, S. 2006, 1416) or, in 
other words, a crossroads of travel, leisure and migration prevail (CoHen, S.A. et al. 2015).

There are several factors that explain Spain's appeal for retired international migrants, although motivation is ultimately always personal (DwYer, P. 2000). Some researchers point out that some of the main factors propelling the flows are related to the so-called 'lifestyle migration' (CASADo-Díaz, M.A. et al. 2004; Torkington, K. 2010; Huete, R. et al. 2013; KING, R. 2015), a complex and nuanced phenomenon that concerns individuals and families who choose relocation as a way of redefining themselves (BENSON, M. and Osbaldiston, N. 2014), searching for nice weather, a better environment or outdoor leisure options, while other scholars have highlighted healthcare as the main reason for such mobility, (HARDILl, I. et al. 2005; BreiviK, J.K. 2012; Legido-Quigley, H. and McKeE, M. 2012; Bell, D. et al. 2015). In any case, the causes can be related to new identities associated to post modern behavioural patterns (Huber, A. and O'Reilly, K. 2004), namely, lifestyle choices inherent to the decision to migrate (BENSON, M. and O'ReILLY, K. 2009) and to the pursuit of self-realization, self-exploration or self-development (Conradson, D. and Latham, A. 2005).

From the point of view of hosting destinations, the importance of this phenomenon is explained by the existence of a competitive supply of homes for sale or for rent in tourism or coastal municipalities (DIAs, J.A. et al. 2015; Rodríguez, V. and DomínguezMujicA, J. 2014); by the governance of second homes and multiple dwellings (HaLL, C.M. and MülleR, D.K. 2004; Hall, C.M. 2015); by the difference in cost of living between the countries of origin and Spain (MCINTYRE, N. et al. 2006; Huete, R. 2008); and by Spain's leading position as a tourism destination in Europe (Rodríguez, V. 2001; Leontidou, L. and Marmaras, E. 2001; O'Reilly, K. 2003).

Without assessing the various causes mentioned, the magnitude of the phenomenon can only be interpreted if we consider that this multifaceted reality involves further dimensions that need to be taken into consid- eration. One of these dimensions is that the presence of European retirees in Spain is not only the consequence of retirement migrants, but also the result of the retirement of labor migrants. Some researchers have studied the presence of retirees who had been working in the same tourism destinations before retiring. Gustafson, P. (2009) analysed the cases of Swedish retirees who had migrated to Spain in their fifties, with the intention of working there, and who become pensioners shortly thereafter. Domínguez-Mujica, J. and Parreño-Castellano, J. (2014) studied the linkages between labour migrants from Northern and Western European and retirees in Spanish tourism destinations.

Nonetheless, there is a flow of lifestyle migrants who were not preparing for retirement, but who retired in the place where they had migrated to. According to Benson, M. and O'Reilly, K. (2009), in such cases, the search for a better quality of life involves a new way of life, where time and working conditions are redefined (MADDEN, L. 1999; Stone, I. and Stuвbs, C. 2007). This migratory model has been analysed in some research, such as that of the British nationals in Costa del Sol (O'Really, K. 2000) or in India (Korpela, M. 2010), but it has generally not received much more attention from scholars.

The characteristics of tourist labor market in Spain have facilitated the success of these migratory projects but the permanence in Spain of these migrants, especially after retirement, can only be explained widening the research from a social perspective. The long-time permanence might be linked to a high level of integration in the hosting society, the development of a family project in Spain, and, in many cases, the creation of transnational identities (Vertovec, S. 1999; Gustafson, P. 2008).

\section{Sources and methodology}

The research is based on three different sets of sources. The first ones are statistical sources from the National Statistical Institute (INE) 
and the Ministry of Employment and Social Security: Continuous Municipal Register Statistics, 2011 Population Census, Residential Variation Statistics and the Spanish Social Security workers registration records.

The second group is comprised by qualitative sources, including 14 semi-structured in-depth interviews developed in the framework of a research project on retirees residing in Spanish tourism destinations. These were conducted in public spaces (cafes, terraces) or at associations in tourism areas of the Spanish Mediterranean provinces and archipelagos during spring 2012. The conversation took place in English or German, depending on the interviewee and on whether the interviewers were native speakers involved in the research project. Besides personal data, questions focused on the decision-making process, the workers' prior status, living arrangements, the identity and belonging feeling, etc. Each interview lasted for one hour approx. and was recorded and transcribed.

The third source corresponds to the microdata from the National Immigrant Survey (ENI) conducted in 2007 by the National Statistical Institute, and to the registration data of workers by the statistical department of the Ministry of Employment and Social Security, the Continuous Sample of Labour Life (MCVL), which lost its original quantitative character once it was processed.

The first source helped develop a descriptive and exploratory statistical analysis; the second one focused on a qualitative analysis and the third one on an observational analysis, following and gathering information of the people under examination for the period of their working and retirement life - 103 people in the case of the National Immigrant Survey and 263 people in the case of the sample of registrations in the Social Security records. All of these sources provided information on Western and Northern European immigrants, including Finnish, Swedish, Norwegian, Icelandic, Irish, Danish, German, Swiss, Austrian, Belgian, Dutch, Luxembourgian, French and British citizens residing in Spanish Mediterranean provinces and archipelagos either as workers or as retired immigrants, focusing particularly on those retirees who carried out their professional careers in Spain.

We examined the professional career that retirees residing in Spanish tourism destinations had developed, by using a quantitative

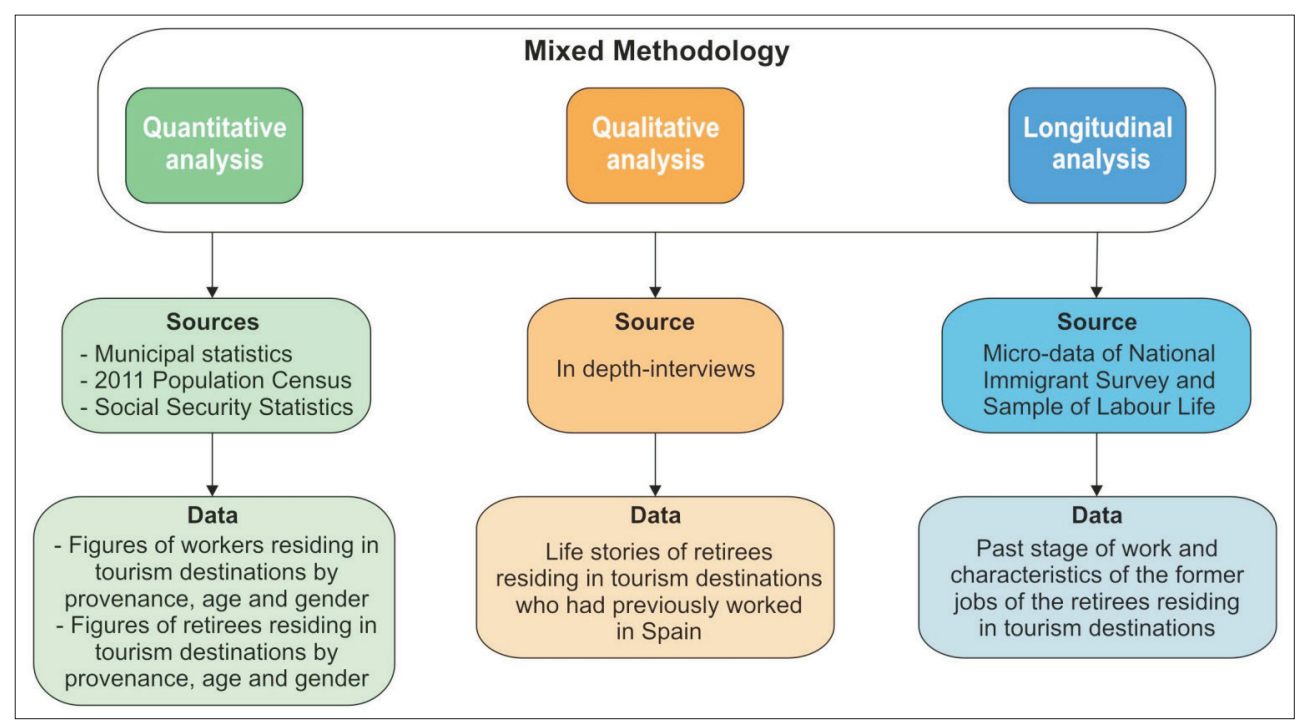

Fig. 1. Scheme of the research proceedings. Source: Compiled by the authors 
procedure followed by a qualitative analysis, leading to certain synergies between both approaches. A mixed methodology was applied as an alternative to the quantitative and qualitative approaches, with the goal of reconstructing the story of the migrant's life. Thanks to this methodology it was possible to collect and interpret data, integrate findings, and draw inferences in a single study of inquiry (TAshakkori, A. and Creswell, J.W. 2007), going back and forth seamlessly between statistical and thematic analysis (Figure 1).

\section{Workers and retirees}

In this section, we study the main characteristics of European workers and retirees in Spanish tourism destinations in order to gather a better contextualisation of the migrants under analysis. Spain has received a substantial flow of migrants from Western and Northern Europe since the 1960s, and especially since the 1990s. According to the 2011 Population and Housing Census, Western and Northern European citizens (Finnish, Swedish, Norwegian, Icelandic, Irish, Danish, German, Swiss, Austrian, Belgian, Dutch, Luxembourgian, French and British) reached 737,872 people, i.e. 14 percent of the total number of foreigners residing in Spain. Figure 2 represents the evolution of the number of these residents according to the information of the Continuous Municipal Register.
Social security registration data record the number of workers and their geographical origin. At the peak of the years of economic expansion (1996-2007), the number of immigrants coming from Western and Northern Europe and enrolling as workers peaked at 181,911. By the end of 2013 that figure had decreased to 155,163 as a consequence of the economic crisis. The main country of origin is the United Kingdom, followed by Germany and France. Most of them were living in the Mediterranean provinces (especially Alicante and Malaga) and in the Balearic and Canary Islands, besides Madrid (Figure 3).

The importance of this group is highly significant for three different reasons. First, as stated by FAvelL, A. $(2009,171)$, 'the numbers of Western Europeans on the move have by no means been large, but they are highly symbolic. For every one who moves to work and settles freely in a neighbouring member state of the EU, many more are moving temporarily... as eventually retirees'. Secondly, the geographical concentration of these workers in the coastal areas is linked inextricably to the development of these locations for mass tourism - and the activities and identities of the migrants themselves, as well as their attitudes, expectations and actions are better understood when we take into account tourism specialization. Lastly, they are likely to remain in Spain after they become retirees, enjoying the rights of European supranational citizenship.

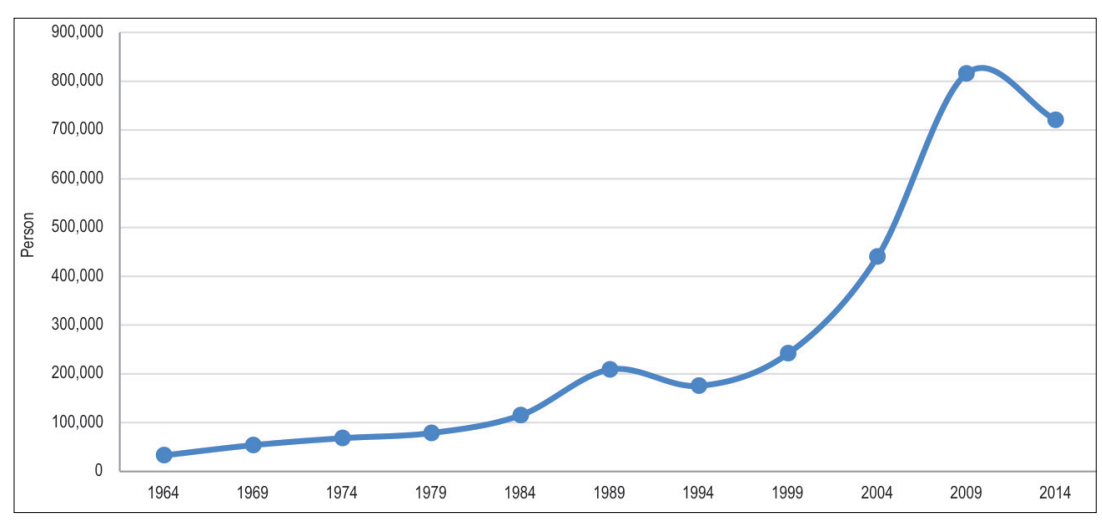

Fig. 2. Western and Northern Europeans residing in Spain. Source: INE Exploitation of the Municipal Register, 2013. 


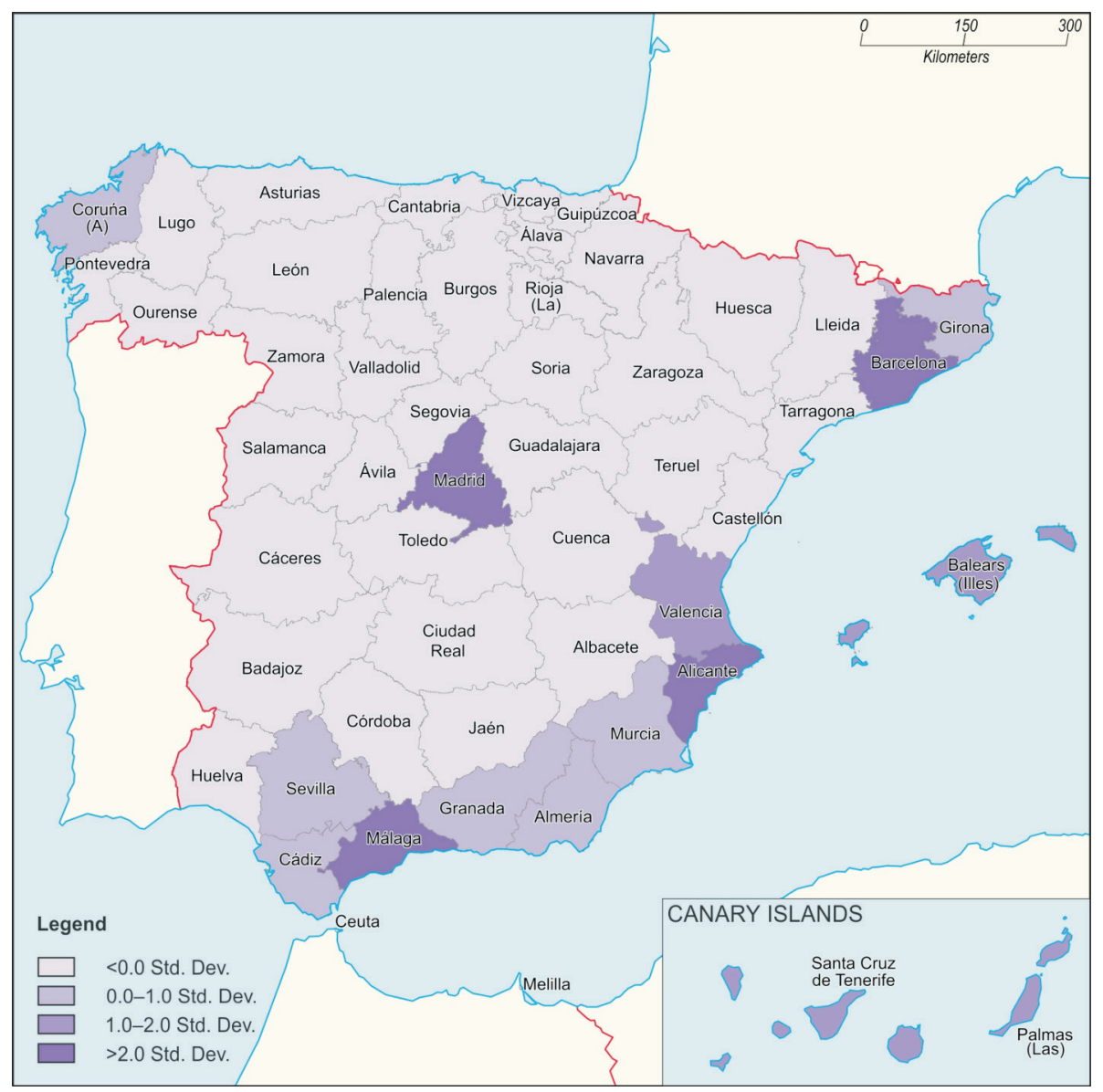

Fig. 3. Geographical distribution of Western and Northern European adult residents (20-59) by provinces. Source: INE Exploitation of the Municipal Register, 2013.

On January 1, 2013, there were 334,388 Western and Northern European citizens over 60 residing in Spain, especially in the coastal municipalities of the Mediterranean and Island provinces (93.8\% out of them), according to the Continuous Municipal Register (Figure 4).

This circumstance indicates the concurrence of both working adults and older residents in the same geographical area. The data from the Residential Variations Statistics show a high influx of these older immigrants since the mid-1990s, with the highest level of settlements between 2004 and 2007. In fact, these numbers would be even higher if we take into account the pensioners be- tween 50 and 60 years of age and the people who voluntarily fail to register with Spanish municipalities. Most of these old residents are British (45.5\%) and German (21.0\%), but there is also an important number of French $(10.2 \%)$, Dutch $(4.8 \%)$, Belgian $(3.9 \%)$ and Norwegian $(3.0 \%)$ nationals.

\section{Building bridges between work and retirement}

This section is devoted to the migrants under examination. In particular, we analyse their quantitative dimension, their demographic 


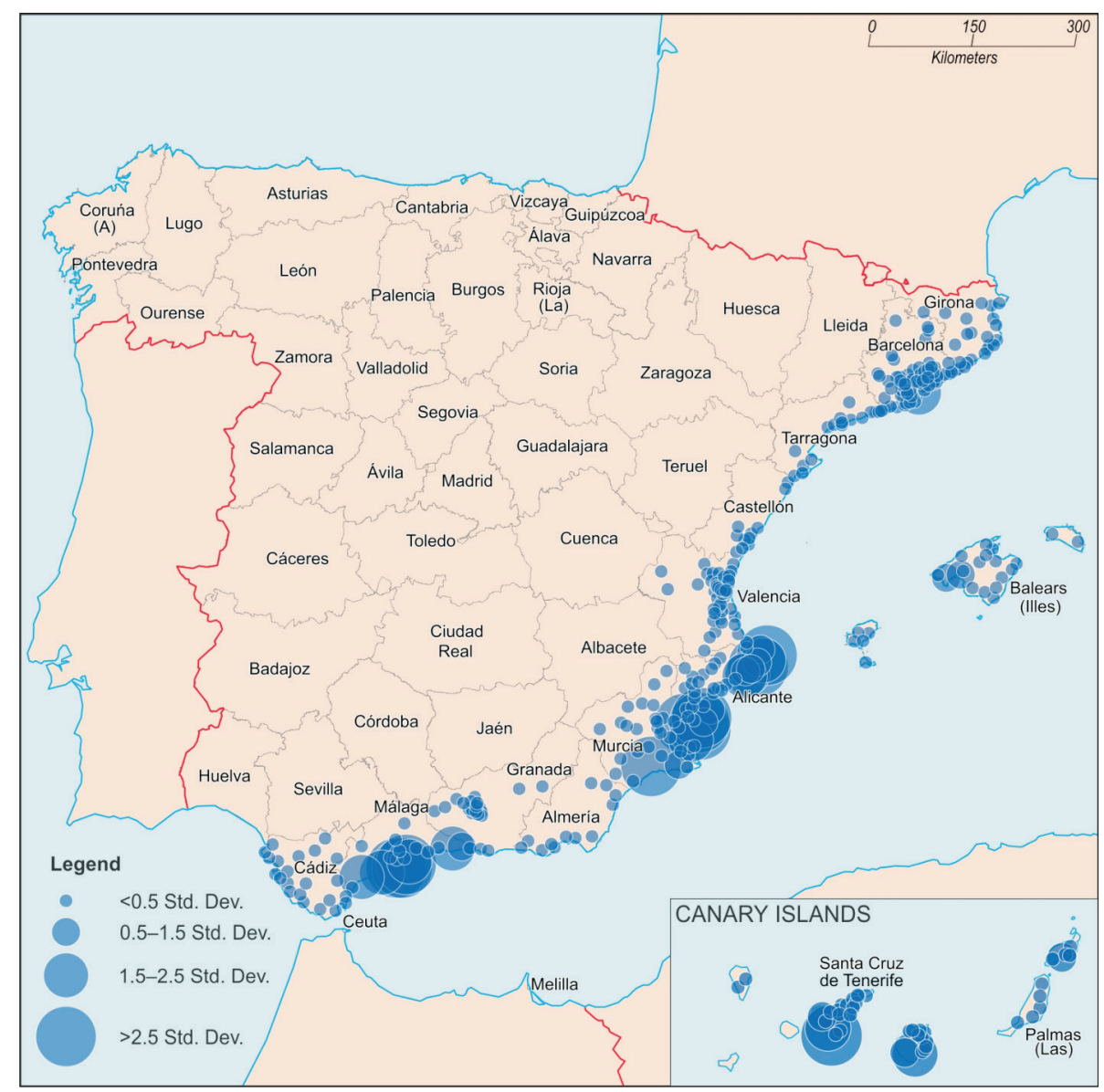

Fig 4. Geographical distribution of older Western and Northern European residents $(>60)$ by municipalities (Mediterranean provinces and islands). Source: INE Exploitation of the Municipal Register, 2013.

profile, and their complex identification as labour migrants and their linkages with tourism.

\section{Statistical evidence}

As noted previously, the relationship between workers and retirees can be ascertained from the information provided by statistical samples. On the one hand, the 2007 National Immigrant Survey (ENI) (2007) interviewed 542 retirees born in Northern and Western European countries and living in the Mediterranean and Spanish Island provinces. Over one hundred of them $(19 \%)$ had worked in Spain before reaching the age of retirement. On the other hand, the Continuous Working Life Sample (MCVL) (2009) contains information about 311 immigrants from the mentioned European countries who received retirement funds from the Spanish Social Security System. This figure represented about 4 percent of the total number of Northern and Western European elderly residents in the Spanish Mediterranean and Island provinces, taking into account the sample size of MCVL.

The difference between both percentages can be explained by the fact that some of the retired immigrants who worked in Spain 
did not meet the requirements to obtain a pension and by the different nature of both sources. Despite this, the combination of them allows us to appreciate the presence of the phenomenon studied and to characterize the demographic and geographical profiles of these immigrants. As expected, most of them were born in France, the United Kingdom and Germany and arrived in Spain before 1980. Both sources also reflect the predominance of males, who normally live alone or, to a lesser extent, with a partner or with a partner and few descendants.

The complex identification of these migrants as labour migrants

According to the data described above, it is obvious that some of the European retirees living in Spain were initially working immigrants. However, is this the consequence of an inflow of labour migrants, or is it a different type of migration?

It is necessary to consider that the subject of our study is a heterogeneous group and, therefore, there is no single answer to the question above. The National Immigration Survey (ENI) data analysed have led us to divide the immigrants we are examining into three distinct groups. Most of them were old adults between 45 and 60 years of age at the time of their arrival in Spain, whose decision to emigrate was often preceded by a family turning point, such as a divorce, a second marriage or the children's independence. The choice to migrate was often linked to the search for new experiences or to the wish to cut ties with the place of birth (in fact, most of them had sold their properties before leaving). We are dealing, therefore, with a group who took the decision to emigrate to bring about a change in their life, moving either alone or with a partner.

The second most important age group is formed by young adults (between 25 and 35 years old), whose decision was related to the wish to begin a professional career, often associated with tourism activities, e.g. holiday representatives, hotel activity lead- ers, sports coaches. Finally, there is a third group formed by the expatriates who had been assigned to a new post in Spain by the company they worked for, i.e. skilled workers, generally in hotel management. This last group includes immigrants of any age, but normally not young adults. All in all, data lead us to consider different motivations in the change of residence.

Therefore, according the ENI, most of immigrants, those of the first group, did not arrive to Spain due to labour motivations sensu stricto. Some characteristics of the immigrants considered in this survey seem weaken the labour character of the majority of the migratory projects. For example, we can mention the fact that a large number $(34 \%$ of the 103 selected immigrants from the ENI) did not speak Spanish before emigrating or that they normally came to Spain without a contract and with only a vague idea of the job that they could get - in fact, only 20 percent of them were hired before migrating.

The in-depth interviews allow us to shed light to the causes of the migratory process. If we analyze some answers together, we might question the labour dimension of this migratory flow. First, the declared motivations. A high number of migrants highlights the lower cost of living and, above all, the search for a 'place in the sun' where to live and not just to work.

'We came on holiday to Moraira and we loved it. Because then it was just a small fishing village, surrounded by palm trees and it was just paradise. One main street, nice tranquil life, it was lovely! And we decided to try. We liked it here, we stayed six months and my parents liked $i t$. They sold their property in England and they bought a restaurant here. And this is how I came to live here' (Sylvia, Moraira, Alicante).

The same factors propelled the so-called 'lifestyle migration' according to Benson, M. and O'Reilly, K. (2009); Torkington, K. (2010) and Huete, R. et al. (2013).

More precisely, in the interviews they refer to the search for nice weather, a better environment and outdoor leisure options. Common, literal explanations by migrants include: 
'At least, here, you can enjoy a lovely lifestyle without spending too much money... so basically, what I try to meet is the lifestyle, and not only the sunshine. I don't like sunbathing. I just like being out in the sun, hiking' (Kim, Los Cristianos, Tenerife, Canary Islands).

'I fell in love with the Spanish way of life' (Nigel, Calvià, Mallorca, Balearic Islands).

In second place, the way which the immigrants tell about the labour situation they lived in their countries of origin. In this sense, none of the immigrants had job difficulties, being either employees or entrepreneurs before departure. They often claim that what they simply wanted was to change their occupation, especially in the case of non-skilled workers. In third place, the low knowledge of the immigrants about Spain and its labour market. Many of the respondents pointed out their absolute lack of contact with Spain or of experience with the country except for a few days' holiday, prior to the migration. This indicates that the decision may have been triggered by television news or reports, tourism flyers, references from acquaintances or their own experience as tourists.

At the same time, there is no shortage of examples of people who came to Spain for a short holiday and decided to stay on and set up a business. As a interviewee said:

'We saw this bar with an apartment and the idea was that it goes over here, get us something to do, earn a bit of money and decided to stay' (Klaus, Empuriabrave, Girona).

Overall, from a personal point of view, this behaviour shows that they are people with initiative, who came to Spain because they wanted to begin or to change their lifestyle. The wish to modify their lifestyle is similar to what generally motivates retirees to migrate, a combination of the receiving areas' features and mechanisms closely linked to the individual's life course (Rodríguez, V. et al. 2004).

\section{A migration project rooted in tourism}

According to the data described above, it would be questionable to classify all these migrants as immigrant workers; however, it is evident that their stay in Spanish destinations is linked to the job opportunities generated by the tourism sector and, consequently, with the existence of a successful migration project. In fact, success at work has tended to provide an incentive for staying in Spain after retirement.

In our research, the two samples show that the most frequent jobs of the respondents were linked to tourism specialization. For instance, 18 percent of the 103 retirees surveyed by ENI and 26 percent of the 263 selected from the MCVL had worked in services of catering and hospitality. Some of the respondents invested their savings in small catering businesses (pubs and restaurants) and hired one or two employees, or worked on their own. Northern and Western European workers selling houses, apartments, bungalows and land in coastal zones and developing activities such as advertising, production of tourism flyers, recreational services or sport activities were also common.

From the point of view of qualifications, 16 percent of the immigrants were managers or technicians, but most of them worked as non-skilled workers - waiters and waitresses, salespersons, real estate agents and manufacturing workers, according to ENI. In spite of this, over two thirds said that they had never been unemployed, which is a sign of a successful migratory project and of the job opportunities that they found in tourism destinations beyond the difficulties of the Spanish labour market. This working condition of immigrants is confirmed by the MCVL. This source indicates that highly skilled employees are a minority (engineers and university graduates represent $13.7 \%$ of the total), compared to the importance of those of lesser categories and administrative officers.

In the case of the hotel trade, we find employees with different levels of specialization, from waiters to hotel managers, but the lesser skilled workers tend to prevail. Nevertheless, the longitudinal analysis allows us to perceive that many of the migratory projects reflect an economic stability and, what is more important, an upward labour mobility. Many 
of the immigrants started out as employees and ended up as owners, developing a successful career.

The professional progress of immigrants, namely the type of work and job stability, has important implications in their decision to stay. The longitudinal perspective provided by the MCVL allows us to identify that those retirees who had their own business or a more stable and better paid employment retired at a higher rate in Spain. The fact that 23.5 percent contributed financially as wage-earners during their working life marks an important difference with respect to the structure of the labour market in Spain, where this rate is much lower, and shows that many of them were entrepreneurs in the different activities promoted by tourism specialization. In contrast, temporary workers are unrepresented not only among retirees but also compared with the figures of this group in the Spanish labour market. Thus, it can be interpreted that this type of job generates fewer roots and plays a significant role when taking the decision to stay or to return.

The relationship between migration project and tourism is also showed by the residential mobility that respondents have had throughout their life. Most of the retirees in Spain live in the same province where they developed their professional career, except for those who had jobs in Madrid, Barcelona and other inland provinces, and who decided to move to coastal areas when they retired. The immigrants that worked in the tourism destinations used to rent an apartment out of those available in consolidated tourism areas, as the obsolescence of some tourism complexes drove them to be offered in the real estate market of housing for workers. In a second stage, as they got better jobs, they tended to move to one of the new tourism urbanizations, frequently in suburban areas.

Factors like career advancement or social support contribute to the modification of the immigrants' dwelling preferences as time goes by. However, the linkages between residential options and tourism specialization remain. As retirees, a part tend to move from consolidated urbanizations to new urbanizations, but always within the same tourism areas, as a consequence of the identity linkages that the respondents have developed.

\section{A migration project linked to the communities of fellow citizens}

As previously stated, tourism activities contribute to offer job opportunities to these migrants but it is also necessary to bear in mind the growth of the communities of active and retired fellow citizens as time goes by, since the growth of this group demands an expanding need for services and, therefore, of job opportunities (O'REILLy, K. 2007).

In fact, most of them have developed their professional activities in close connection with fellow country people, working at pubs and restaurants, selling property to foreign investors, normally of their own geographical origin, renting cars, entertaining tourists through leisure activities, taking care of elderly retirees, etc. Hence, their social space is an in-between space (Levitt, P. and Schiller, N.G. 2004).

As a consequence, many of these foreigners display a relatively low level of integration in their local communities, as reflected in the answers collected by the ENI and the interviews. For example, both sources show that they do not usually participate in politics or vote in the elections (JANOSCHKA, M. and DurÁN, R. 2013):

'The politics I thought were... I had no vision, just a tourist view... I haven't been interested in politics' (Michael, Torremolinos, Málaga).

'I'm never as interested in politics as to be involved' (Hugh, Mojácar, Almería).

Additionally, the same sources reveal that they generally only take part in social clubs or associations when they are promoted by or organized for fellow citizens:

'I would find myself here amongst the Germans at the German club / Deutscher Club Costa Blanca' (Sylvia, Moraira, Alicante).

'I am a member of the $41 \mathrm{Club}$, which is more like a dining club' (Nigel, Calvià, Mallorca). 
This reveals a tendency to 'seek out their own' (KING, R. 2002; WARnES, T. and Williams, A. 2006: 137). This behaviour is similar that of retirement migrants. In interviews conducted by O'ReILLY, K. with British (2000) and by Gustafson, P. (2002) with Swedish retirees, the residents recognized that they felt more foreign than Spanish in Spain, and they did not consider a full integration possible or desirable. In this sense, as stated by BREIVIK, J.K. (2012, 1650) regarding Norwegians, 'being Norwegian in Spain is made by a combination of pride and shame, enthrallment and struggle, integration and separation'. In our research, most of the respondents were not especially worried about integration. They had found strategies for everyday life and come to interpret when they had to deal with specific situations of legal or administrative nature, appreciating the efforts made to assist in their own language by municipalities.

Nevertheless, this lack of interest about the benefits of a greater integration does not preclude having a feeling of identity with the environment in which they develop their daily lives. In this sense, they often claim to wish remain in Spain to the end of their days, to the point that some of them manifest they wish to die in Spain:

'It is a good place to grow old (...) where there is warm weather and could die comfortably' (British, 68 years old man, retiree, former teacher of English language).

Similarly, they develop certain behaviours of socially integrated citizens, such as homeownership (67\% of the 103 selected immigrants from the ENI purchased a house). All in all, we can say that they develop a personal project of social integration in which a certain sense of transnational identity is balanced with a tourist gaze of life.

\section{Conclusions}

In this research, we have confirmed the importance of in-depth interviews and the structural and longitudinal analysis of per- sonal micro-data from statistical sources to study the professional and personal paths of immigrants in tourism destination. Our research is based on the realisation that there are two distinct groups of Northern and Western Europeans residing in Spain. On the one hand, the group made up by those who have arrived during their working lives, from the 1960s on, to enter the labour market and, on the other hand, migrating retirees. The former, whose numbers have grown steadily, has been quantified statistically thanks to the data offered by the Continuous Municipal Register Population, 2011 Housing Census and the Spanish Social Security records. The latter group, which has also grown substantially, has done so at a slightly later stage, from the beginning of the 1990s, as revealed by the Municipal Census and the Residential Variation Statistics. In both cases, the most common residential destinations are Spain's Mediterranean coastal regions and both Spanish archipelagos.

Our paper proposes that there is a certain link between both groups, demonstrating the bridges between labour and retire migrations. The presence of the retirees is not only the consequence of the international migration of retirees, but also of the fact that some of these retirees had formerly been workers who had migrated to Spain during their working years. Our study has allowed us to establish the contribution of these former workers to the number of retired pensioners, who can otherwise be mistaken for immigrants who had arrived after retirement. However, when examining this migration process in greater depth, we realize that its origin is not, in a strict sense, that of a migration of workers.

There are other features in this process that contribute to distort its character as a workers migration flow, or at least, set it apart from other more usual work migration processes: the low use of support networks at their host destination (at least during the first years in Spain); the lack of a contract of employment before emigrating; the absence of a clear idea regarding the kind of job they 
wished to find in Spain; their limited proficiency in Spanish; the fact that they do not send remittances back to their home country; or the little prior contact they had had with host areas (and, consequently, with their job markets). Likewise, the fact that the immigrants highlight good weather, the environment or quality of life as factors that had led them to come and look for work in Spain equates them to retired or lifestyle immigrants, as explained by previous studies (Huete, R. et al. 2013).

Consequently, we believe that we are dealing with people who brought their dream life forward in a tourism environment during their working life, a phenomenon which, although partly examined by other studies (O'Really, K. 2000, Gustafson, P. 2009; LunT, N. 2009), has attracted less attention in tourism research. This, in turn, shows the complexity of human mobility in tourism destinations, where the limit between older people who migrate and former labour migrants who have 'aged in place' is blurred (Warnes, T. and Williams, A. 2006, 1257).

Another question of great importance is the factors that condition the permanence of these working migrants. Among them, we have emphasized the labour opportunities and the job success that tourism offers in Spain. There is a link between qualifications, work stability and promotion on the one hand and their permanence on the other, both during their working life and after retirement. Also, we would like to underline the fact that the development of communities of fellow country people made up of active and retired in areas where working migrants reside ends up becoming a key element when explaining the permanence in Spain of former migrants. This is because many of them held jobs closely linked to niches of activities generated by the very existence of these communities, and also because they developed a social life linked to their fellow citizens, as their leisure preferences and social relations reveal.

Precisely this second element has been highlighted as an explanatory factor in the study undertaken by CaSADo-Díaz, M.A. et al. (2014). Thus, we might wonder how many of those active migrants might have taken the decision to stay in Spain if they had not found fellow expatriate communities. Although we cannot establish exact figures, the analysis of in-depth interviews reveals the importance that for their lifestyle their integration in those communities indeed had. For all these reasons, we believe that these immigrants have developed a personal process with a balance between integration and identity, leading them to generate transnational identities.

\section{REFERENCES}

BAKewell, O. 2010. Some reflections on structure and agency in migration theory. Journal of Ethnic and Migration Studies 36. (10): 1689-1708.

Bell, D., Holliday, R., Ormond, M. and Mainil, T. 2015. Transnational healthcare, cross-border perspectives. Social Science and Medicine 124. 284-289.

Benson, M. and O'Reilly, K. 2009. Migration and the search for a better way of life: a critical exploration of lifestyle migration. The Sociological Review 57 (4): 609-625.

Benson, M. and Osbaldiston, N. 2014. Understanding lifestyle migration: Theoretical approaches to migration and the quest for a better way of life. Hampshire, Springer.

Božıć, S. 2006. The achievement and potential of international retirement migration research: The need for disciplinary exchange. Journal of Ethnic and Migration Studies 32. (8): 1415-1427.

BreiviK, J.K. 2012. Health migration from Norway to Spain - Ambiguous belonging. Ethnic and Racial Studies 35. (9): 1634-1653.

Casado-Díaz, M.A., Casado-Díaz, A.B. and CasadoDíAz, J.M. 2014. Linking tourism, retirement migration and social capital. Tourism Geographies 16. (1): 124-140.

Casado-Díaz, M.A., Kaiser, C. and Warnes, A.M. 2004. Northern European retired residents in nine southern European areas: characteristics, motivations and adjustment. Ageing and Society 24. (3): 353-381.

Cohen, S.A., Duncan, T. and Thulemark, M. 2015. Lifestyle mobilities: The crossroads of travel, leisure and migration. Mobilities 10. (1): 155-172.

Conradson, D. and Latham, A. 2005. Transnational urbanism: attending to everyday practices and mobilities. Journal of Ethnic and Migration Studies 31. (2): 227-233.

Dias, J.A., Correia, A. and López, F.J.M. 2015. The meaning of rental second homes and places: the 
owners' perspectives. Tourism Geographies 17. (2): 244-261.

Domínguez-Mujica, J. and Parreño-Castellano, J.M. 2014. Trabajadores y retirados. La flexible condición de los migrantes del Oeste y Norte de Europa en los destinos turísticos de España. Boletín de la Asociación de Geógrafos Españoles 64. 65-80.

Dwyer, P. 2000. Movements to some purpose? An exploration of international retirement migration in the European Union. Education and Ageing 15. (3): 353-375.

FAVELl, A. 2009. Immigration, migration and free movement in the making of Europe. In European identity. Eds.: Checkel, J.T. and Katzenstein, P.J., Cambridge, Cambridge University Press.

Gustafson, 2008. Transnationalism in retirement migration: the case of North European retirees in Spain. Ethnic and Racial Studies 31. (3): 451-475.

Gustafson, P. 2002. Tourism and seasonal retirement migration. Annals of Tourism Research 29. (4): 899-918.

Gustafson, P. 2009.Estrategias residenciales en la migración internacional de jubilados. In Turismo, urbanización y estilos de vida: las nuevas formas de movilidad residencial. Ed.: Mazón, R., Huete, R. and Mantecón, A., Barcelona, Icaria.

HaLl, C.M. 2015. Second homes planning, policy and governance. Journal of Policy Research in Tourism, Leisure and Events 7. (1): 1-14.

Hall, C.M. and MüLleR, D.K. 2012. Tourism, mobility, and second homes: between elite landscape and common ground. Clevedon, Channel View Publications.

Hardill, I., Spradbery, J., Arnold-Boakes, J. and MarrugAt, M.L. 2005. Severe health and social care issues among British migrants who retire to Spain. Ageing and Society 25. (05): 769-783.

Huber, A. and O'ReILly, K. 2004. The construction of heimat under conditions of individualised modernity: Swiss and British elderly migrants in Spain. Ageing and Society 24. (3): 327-352.

Huete, R. 2008. Turistas que llegan para quedarse. Motivos para el traslado residencial al Mediterráneo español. $\mathrm{PhD}$ dissertation, Alicante, University of Alicante.

Huete, R., Mantecón, A. and Estévez, J. 2013. Challenges in lifestyle migration research: Reflections and findings about the Spanish crisis. Mobilities 8. (3): 331-348.

Huete, R., Mantecón, A. and Mazón, T. 2008. ¿De qué hablamos cuando hablamos de turismo residencial? Cuadernos de Turismo 22. 101-121.

Janoschka, M. and Durán, R. 2013. Lifestyle Migrants in Spain. Contested Realities of Political Representation. In Contested Spatialities, Lifestyle Migration and Residential Tourism. Eds.: JANOschKA, M. and HaAs, H., London, Routledge, 60-73.

KING, R. 2002. Towards a new map of European migration. International Journal of Population Geography 8. (2): 89-106.
KING, R. 2015. Sunset migration. In An introduction to international migration studies: European perspective. Ed.: Martiniello, M. and Rath, J., Amsterdam, Amsterdam University Press.

King, R., Warnes, T. and Williams, A. 2000. Sunset lives: British retirement migration to the Mediterranean. Oxford-New York, Berg.

Korpela, M. 2010. Me, Myself and I: Western Lifestyle Migrants in Search of Themselves in Varanasi, India. Recreation and Society in Africa, Asia \& Latin America 1. (1): 53-73.

Legido-Quigley, H. and McKee, M. 2012. Health and social fields in the context of lifestyle migration. Health and Place 18. (6): 1209-1216.

Leontidou, L. and Marmaras, E. 2001. From tourists to migrants. Residential tourism and 'littoralization'. In Mediterranean tourism: Facets of socioeconomic development and cultural change Eds.: Apostolopoulos, Y., Leontidou, L. and Loukissas, P., London, Routledge.

Levitt, P. and Schiller, N.G. 2004. Conceptualizing Simultaneity: A Transnational Social Field Perspective on Society. International Migration Review 38. (3): 1002-1039.

LunT, N. 2009. Older people within transnational families: the social policy implications. International Journal of Social Welfare 18. (3): 243-251.

Madden, L. 1999. Making Money in the Sun: The Development of British-and Irish-owned Businesses in the Costa del Sol. Research Papers in Geography 36. Brighton, University of Sussex.

McIntyre, N., Williams, D. and McHugh, K. 2006. Multiple dwelling and tourism: Negotiating place, home and identity. Oxfordshire, CABI.

O'Reilly, K. 1995. A new trend in European migration: Contemporary British migration to Fuengirola, Costa del Sol. Geographical Viewpoint 23. (1): 25-36.

O'Reilly, K. 2000. The British on the Costa del Sol: Transnational identities and local communities. Oxon, Psychology Press.

O'ReILly, K. 2003. When is a tourist? The articulation of tourism and migration in Spain's Costa del Sol. Tourist Studies 3. (3): 301-317.

O'Reilly, K. 2007. Emerging tourism futures: Residential tourism and its implications. In Going Abroad: Travel, Tourism and Migration. Cross Cultural Perspectives on Mobility. Eds.: Geoffrey, C. and Sibley, R., Newcastle, Cambridge Scholars.

Rodríguez, V. 2001. Tourism as a recruiting post for retirement migration. Tourism Geographies 3. (1): 52-63.

Rodríguez, V. and Domínguez-Mujica, J. 2014. Cuando el lugar importa: preferencias residenciales de los inmigrantes jubilados en España. In 'A Jangada de Pedra' Actas do XIV Colóquio Ibérico do Geografia. Guimaraes, Universidade do Minho, 360-365. 
Rodríguez, V., Fernández-Mayoralas, G. and Rojo, F. 2004. International retirement migration: Retired Europeans living on the Costa del Sol, Spain. Population Review 43. (1): 1-36.

Stone, I. and StubBs, C. 2007. Enterprising expatriates: lifestyle migration and entrepreneurship in rural Southern Europe. Entrepreneurship and Regional Development 19. (5): 433-450.

Tashakkori, A. and Creswell, J.W. 2007. The new era of mixed methods. Journal of Mixed Methods Research 1. (1): 3-7.

Torkington, K. 2010. Defining lifestyle migration. Dos Algarves 19. 99-111.
Vertovec, S. 1999. Conceiving and researching transnationalism. Ethnic and Racial Studies 22. (2): $447-462$.

Warnes, T. and Williams, A. 2006. Older Migrants in Europe: A new focus for migration studies. Journal of Ethnic and Migration Studies 32. (8): 1257-1281.

Williams, A. and Hall, C.M. 2000. Tourism and migration: new relationships between production and consumption. Tourism Geographies 2. (1): 5-27.

Williams, A. and Hall, C.M. 2002. Tourism and migration: New relationships between production and consumption. London, Kluwer Academic Publishers. 